\title{
Research on language and gender in Iceland: History and current trends
}

\section{Finnur Friðriksson}

\section{Introduction}

Each of the two terms referred to in the title above has long been on the agenda in both scientific circles and the public debate in Iceland. Thus, Icelanders often pride themselves on being in the forefront, even in an international context, when it comes to equal rights, regardless of whether this refers to women's standing in society or the rights of groups that in one way or another deviate from the heterosexual norm that dominates, at least historically, most societies. For example, Icelandic women officially gained the parliamentary vote on 19 June 1915 - although this right was initially limited to women who were aged 40 or over but at that time only a handful of countries had taken this step. In more recent times, Vigdís Finnbogadóttir became the first woman to be elected head of state in a democratic election when she won the presidential elections in Iceland in 1980. Three years later, Kvennalistinn (The Women's List), a feministic political party, was formed and it was to become quite influential in Icelandic politics until 1999 when it merged with other parties on the left of the political spectrum. Then, in 2009 Jóhanna Sigurðardóttir, who then led Samfylkingin (The Social Democratic Alliance), became Iceland's first female prime minister, thereby joining a rather select group of women around the world who held or had held such a post.

Jóhanna Sigurðardóttir's appointment as prime minister was also quite a landmark in the growing movement for LGBT rights in Iceland, as well as on an international level, as she was the world's first openly lesbian head of government. It can be claimed that the official starting point of the LGBT rights movement in Iceland was the foundation of Samtökin '78, The National Queer Organization, in 1978 and other important steps include e.g. the passing of anti-discrimination laws in 1996 and a gender-neutral marriage law in 2010. In general, the feministic and equal rights debate is quite lively, and so it has been for a number of years, and even though a number of issues still need to be addressed, Iceland is undoubtedly one of the world's most gender-equal countries and the general stance towards LGBT rights is liberal and relaxed.

In a similar way to equal rights, language is a frequently discussed topic in the general debate in Iceland, even though it may not have had as strong political implications in recent years, and the generally strong linguistic awareness is witnessed e.g. by the fact that one of the most popular television shows in Iceland over the last few years, Orðbragð, discusses various aspects of the Icelandic language in an accessible and often humorous way. Also, one does not need to observe Icelanders' use of social media for long to notice that language and the use and/or misuse of it often gives rise to heated debate. Furthermore, research indicates that the Icelandic language plays an integral part in the national identity of Icelanders (Friðriksson 2008), although recently the claim has been growing stronger that both the language and the national identity are being increasingly threatened by a growing use of 
English and a more lenient stance towards this development. The first official Icelandic language policy, implemented in 2009, is in many ways a direct reaction to this as it emphasizes the use of Icelandic in all domains of public life (Íslenska til alls 2009). As for the scientific context, there is a long tradition of research on Icelandic and the research community is thriving, with most aspects of the Icelandic language being studied in one way or another.

Having now seen that both language and gender are firmly established topics for discussion in Iceland, it would be easy to assume that they have frequently been combined for an examination of the various aspects of the interplay between them. This, however, has been the case to only a very limited extent, both in scientific circles and in the public debate. Thus, in one of the first academic attempts to address the issue of language and gender in an Icelandic context, Gunnarsdotter Grönberg (2002:176) writes that:

There are a small number of Icelandic articles and student papers on language and gender issues. The leading researchers in the departments of linguistics and Icelandic at the University of Iceland are mainly specialized in the fields of philology, generative grammar, lexicography and language cultivation, and therefore there has not been much scope for either sociolinguistics in a broad sense ... or research on language and gender (Gunnarsdotter Grönberg 2002:176).

While some progress has certainly been made since 2002, Gunnarsdotter Grönberg's comment is still highly relevant as the academic interest in Iceland in language and gender has been quite limited, among both linguists and researchers working in related fields. Similarly, issues regarding language and gender have only emerged quite sporadically both in Icelandic media and in the public debate that is carried out there and on various social media. This does not mean, however, that these issues have not been touched upon at all, and it is the purpose of this article to give an overview of the language and gender related topics that have been discussed, among both researchers and the general public, and to present some of the main findings of the - all too few - studies that have been carried out.

When the full range of studies and discussions on language and gender in an Icelandic context is examined it quickly emerges that, even though there is very little history to speak of in this regard, as indicated by Gunnarsdotter Grönberg's (2002:176) comment referred to above, recent and/or current trends can be divided into three main categories. These are (1) Feminist and/or queer language reform; (2) Gendered discourse; and (3) Gender and language use. In what follows, the discussion will be structured roughly along these lines even though the categories are not mutually exclusive in all instances, as some studies touch on more than one of them and the public debate tends to roam rather freely from one topic to another. Similarly, even though the main focus will be on what scientific work there exists, the lines between the scientific debate and the public debate may at times be a little unclear as in some cases the research community is in a direct debate with the general public at the same time as the public debate often adds valuable insights to the results of the more structured scientific work. Finally, in the discussion on the last of the three categories mentioned earlier, attention will be given to ongoing work by the author of this article. 


\section{Feminist and/or queer language reform}

As may perhaps be gleaned from the introduction, there is a strong feministic movement in Iceland and this can be said to be the main source of inspiration for a large part of both the scientific work that exists on language and gender in Iceland and the public debate on the topic. Not least of all, feminists have been the leading figures behind attempts at language reforms which aim at making the feminine gender more prominent in the Icelandic language. As pointed out by Gunnarsdotter Grönberg (2002:171-172), there is a tendency in Icelandic to use masculine as a generic or unmarked gender when referring to a person of unknown gender or a heterogeneous group of people, which results in phrases such as "allir (m.pl.) velkomnir (m.pl.)", i.e. "everybody welcome". This tendency appears to have gone mostly unnoticed and uncontested throughout the history of Icelandic and it was not until a new Bible translation was commissioned, and subsequently published in 2007, that the first real and persistent calls for change emerged. This was led by a group of feminist theologians within the Church of Iceland who, partly inspired by the growing international debate on feminist language reform, as discussed in e.g. Pauwels (1998), claimed that "mál beggja kynja" ("the language of both genders") should be used in the Bible, which called for a series of modifications to what in the eyes of this group was a predominantly masculine language. In their argumentation for this change the group leaned somewhat towards linguistic relativism through their claim that via the generic use of the masculine everyday Icelandic was in many ways discriminatory towards women and that rather than being mentioned directly in texts women had to look specifically for places where they were being referred to. In more concrete terms they wanted to change e.g. "Sá (m.sg) sem trúir á mig mun lifa pótt hann (m.sg) deyi" ("He who believes in me will live even though he dies"; John 11:25) to "Pau (n.pl) sem trúa á mig munu lifa pótt pau (n.pl) deyi" ("They who believe in me will live even though they die") (Vilhjálmsdóttir 2005:43).

To cut a relatively long story short the feminist theologians were granted their wishes, at least in part, and the translation committee was instructed to take their standpoint into consideration. The results can be divided into two main categories. On the one hand, a certain level of feminization and/or gender specification was reached through vocabulary choices, such as through the usage of systkin ("siblings") instead of the earlier braður ("brothers") in certain places where it seems clear that the reference includes both genders. On the other hand, the generic use of masculine forms of pronouns and adjectives was replaced, where it was deemed to be necessary due to the context, with neuter forms, such as in the example above (“Sá sem trúir á mig...” $\rightarrow$ "Pau sem trúa á mig...”) (Pórhallsdóttir 2008).

As could perhaps be expected, the proposed feministic reforms met some scepticism, among both general churchgoers and more traditional branches of the Church of Iceland. Interestingly, some linguists also expressed their doubts about the use of "mál beggja kynja" in the new translation. While making women more visible through the choice of vocabulary was seen as relatively unproblematic, the proposed deviation from using masculine generics and from regarding gender as strictly grammatically determined, was argued to cause too dramatic changes to the morphological and syntactical structure of Icelandic. Furthermore, the feminist theologians' claims about the linguistic relativism of Icelandic, i.e. that the use of masculine generics caused Icelandic to be, in a sense, male-oriented, were not accepted as no 
clear evidence corroborated that speakers of Icelandic interpreted the masculine generics in this way (Pórhallsdóttir 2005; 2008). Interestingly, however, the findings of a recent M.A. thesis (Helgadóttir 2011) suggest that in their language use Icelandic teenagers, boys in particular, lean increasingly towards semantic or biological agreement, at the expense of grammatical agreement. This means e.g. that many members of this group now use the neuter pronoun pau ("they") to refer to the masculine noun krakkar ("kids") instead of the masculine peir required by standard language. Similarly, a phrase such as "Hjúkrunarfræðingurinn (m.sg) var skemmtileg (f.sg)" ("the nurse was funny") now seems to be an option if the nurse in question is a woman, thereby bypassing the grammatical gender agreement required by standard language between the noun and the adjective. Nonetheless, within Icelandic linguistics, feminist language reform is yet to be met with the same level of interest or acceptance it appears to have reached within linguistics in much of the Western world (see e.g. Eckert \& McConnell-Ginet 2003; Edlund, Erson \& Milles 2007).

Apart from the debate described above, a number of smaller feminist language reform issues have emerged from time to time in the public debate. One of the first of these followed the previously mentioned election of Vigdís Finnbogadóttir as president in 1980. Vigdís Finnbogadóttir herself is, of course, a woman while the title forseti ("president") is masculine and this resulted in some uncertainty amongst Icelanders, not the least journalists and news reporters, about whether to use the male personal pronoun hann ("he") or the female pronoun hún ("she") when referring to the president (Gunnarsdotter Grönberg 2002:168). Similarly, the traditional Icelandic terms for "minister" and "member of parliament" are, respectively, ráðherra and pingmaður, both of which are masculine. On a number of occasions this has been the source of discussions, both in the Icelandic parliament and outside it, about whether more gender neutral terms should be introduced. As regards ráðherra no change seems yet to be in sight while the term pingkona (literally: "parliament woman") is now quite commonly used both in the media and amongst the general public for female members of parliament, even though the parliament itself has not followed suit. It can be added that Helgadóttir's (2011) M.A. thesis mentioned above also investigated the acceptance amongst the general public, especially teenagers, of gender-neutral or feminized forms of this kind and found it to be on the rise.

Another issue which has been addressed from time to time by those who lean towards feminist language reforms is the generic use of maður, which closely resembles the generic use of man in Swedish or the use of one in English in phrases such as "Hvernig segir maður petta?" (Swedish: "Hur säger man detta?"; English: "How does one say this?”). Traditionally, women have used this masculine word, maður, in its generic sense in the same way as men have done, but even though the "resistance movement" in this case does not seem to be structured in any clear way, the use of kona ("woman") instead of maður has in recent years been increasingly observable in the relevant contexts amongst women writing e.g. blog posts or on various social media. This development bears some resemblance to a recent increase in the use of generic en rather than man in Swedish (Institutet för språk och folkminnen 2015), where the aim is to reach a more gender neutral usage. Arguably, though, the Icelandic trend is somewhat more radical in that it involves a switch from a masculine to a feminine term, rather than a neutral one, for generic use. How far this use has reached is, however, quite unclear as no scientific studies exist on the subject. 
As a final example of the feminist language reform debate in Iceland in recent years an article posted by Hildur Knútsdóttir (2013a) on a feminist website called Knúz can be mentioned. In the article, which was posted in the spring of 2013, Knútsdóttir claimed, in many ways along the same relativistic lines as the feminist theologians earlier (Vilhjálmsdóttir 2005), that through e.g. the use of generic masculine and other structural features, Icelandic is a male-oriented language which oppresses women. The article sparked quite a heated debate which went on for a few weeks in the comments field on the Knúz website and, again, the strongest reply came from the linguistics camp, but Iris Edda Nowenstein, who was at the time a master's student of linguistics (2013) posted a separate article, entitled "Að gera málkerfið að karlrembusvíni” ("Turning linguistic structure into a male chauvinist pig”), where she argued strongly against the linguistic relativism that influenced Knútsdóttir's original article despite otherwise sharing Knútsdóttir's feminist agenda. Knútsdóttir (2013b) swiftly replied to Nowenstein's objections, reiterating her initial standpoint, but after this the discussion ebbed out and the issue has not come to the surface again in any prominent way.

The debate on language reform in relation to gender has not only circled around feminism as the queer community in Iceland has also made its voice heard and demanded certain amendments, much in line with similar developments abroad where both the queer community and linguists have discussed e.g. the heteronormativity and even homophobia that is often evident in the general debate on sexuality (see e.g. Eckert \& McConnell-Ginet 2003; Edlund, Erson \& Milles 2007; Kulick \& Cameron 2003; Milani 2014; Queen 2014). As is the case with feminist language reform, queer language reform has received very limited attention in the scientific community in Iceland, but Póra Björk Hjartardóttir's (2004) article on the words used in Icelandic to refer to homosexuality is an interesting exception. In the article, Hjartardóttir relates how, shortly after the formation of the above-mentioned Samtökin ' 78 in 1978, the gay community started fighting for the general acceptance and use of the terms that its members used to refer to themselves, i.e. hommi and lesbía (a "a gay man" and "a lesbian"). Today, these terms may seem harmless enough, but in 1981 RÚV, the Icelandic National Broadcasting Service, refused to broadcast an announcement from Samtökin '78 where hommar and lesbiur ("gays" and "lesbians") were called to a meeting. If the announcement was to be read on the radio terms such as kynvillingur or kynhvarfi (both terms can be translated as "sexually deviant") should be used. This sparked a wave of protests from the gay community, and it seems that it was quite successful in its fight as from around the mid-eighties hommi and lesbia, and a few other terms used by the gay community to refer to their sexual orientation, have replaced older and more negatively charged terms which had been more or less forced upon this group. Interestingly, however, even here a slight gender bias seems to have crept in, as hommi appears to be more generally used than lesbía, probably as a result of men being, in general, more central in the public debate (Hjartardóttir 2004).

Much in line with a broadening of the scope of Samtökin '78, queer language reform has, in the last few years, also tackled the problems faced by people who, in one way or another, do not find their place in the traditional binary opposition between men and women or even between straight and gay people. Thus, Alda Villiljós, a leading figure in the gender queer or gender fluid community in Iceland, posted an article on the above-mentioned feminist website Knúz in the September 2013. In the article, Villiljós discusses the problems faced by gender fluid people, both in terms of finding their place in the gender spectrum and as regards 
how these people can refer to themselves as the Icelandic language simply lacks terms that describe their placement in this spectrum in any precise way. Villiljós then mentions that in 2012 they ${ }^{1}$ moved to Sweden, where they came across the pronoun hen, which had then recently been introduced in the country to replace hon or han ("she" or "he") where relevant, either because of gender fluidity or to avoid specifically marking either gender in the context in question. On this basis, Villiljós suggests that hán be introduced in Icelandic for use in contexts where hún or hann ("she" or "he"), or even pað ("it"), are not appropriate or precise enough. Villiljós rounds off their ${ }^{2}$ article by pointing out that every now and then they run into people who refuse to use pronouns they would like them to use and point out that they are simply wrong or unnecessary as pað can be used instead. Villiljós's response to this is that language is created and shaped by the people who use it and that new words and wordforms are constantly added to it.

It is still too early to tell whether hán will become established in Icelandic in similar way to hen in Swedish, and no formal examination has yet been carried out on the possible inroads it has made. Nonetheless, it has been formally presented, by Alda Villiljós, to the Icelandic Linguistics Society, at a seminar in September 2015 and at about the same time it made its first "public appearance" when it appeared in the Icelandic subtitles to an episode of Bron ("The Bridge"), a Danish-Swedish crime series which is highly popular amongst Icelandic viewers, as a translation to the Swedish hen when it was used by one of the characters in the series. However, some of the reactions to hán, witnessed by the author of this article on various social media and blog posts, suggest that there is still a long way to go before general acceptance is reached.

As a final note regarding queer language reform, it can be added that in August 2015 Samtökin '78 launched a competition called Hýryrði 2015 (Queer Words 2015). In this competition the general public was invited to suggest neologisms for a set of 16 queer terms, in four different categories: sexual expression, sexual awareness, sexual orientation and gender-neutral kinship terms. A panel of judges, including e.g. linguists, translators and members of the queer community, was appointed and results were announced on 16 November, which is called Dagur islenskrar tungu, i.e. the Official Day of the Icelandic Language. More than 300 suggestions were received and the winning contributions included terms such as dulkynja or vífguma for "androgynous", and bur, a neuter word for sonur/dottir, "son/daughter". At the same time, Samtökin '78 point out that the results should not be seen as final, but rather as suggestions for further discussion and experimentation, as it is imperative that the terms are generally accepted by the people they refer to (Samtökin '78 2015a, Samtökin '78 2015b).

\footnotetext{
${ }^{1}$ The appropriate use of pronouns in this context is just as problematic in English as it is in Icelandic, and a number of suggestions have been put forth regarding which form should be used. The use of singular they here follows Alda Villiljós's own preference, as expressed in personal communication with the author of this article. Villiljós claims that this is the most commonly used form in the English-speaking gender fluid community.

${ }^{2}$ Here again, Villiljós's preferred form is used.
} 


\section{Gendered discourse}

Just as in other parts of the world where feminism has grown strong in the last few decades, some attention has been paid in Iceland to the potential imbalance between how men and women are portrayed and talked about in the public discourse, as it appears in e.g. mass media and, more recently, social media. As will become evident shortly, the issues addressed in this respect in Iceland are much the same as elsewhere, including e.g. the tendency to let men take centre stage in the public debate on most aspects of society, and to focus on women solely as women, rather than as e.g. professionals of various kinds, on the occasions that they are included in the debate (see e.g. Kendall \& Tannen 2003).

We will start our discussion here in the sports section as the Icelandic interest in gendered discourse has, for some reason, been particularly evident, both in academic circles and in the public debate, in relation to sports and how male vs. female athletes are treated on newspapers' sports pages and in sports broadcasting. However, this particular attention that is paid to this part of media may be justified by some of the results of the academic studies that exist as well as the issues that have emerged amongst the general public. Thus, a report by Ólafsson and colleagues (2006) indicated that there are considerable differences, in terms of both quality and quantity, between how Icelandic media covered men's sports on the one hand and women's sports on the other, as female athletes only got about $10 \%$ of the coverage and were rarely put on a pedestal in this coverage in the same way as male athletes. These findings were confirmed a few years later, in a master's thesis by Daðason (2011), who found that women held only an $11 \%$ share of Icelandic media's online coverage of sports and that female athletes were interviewed and quoted to a far lesser degree than male athletes. Furthermore, non-Icelandic female athletes were mentioned only very sporadically in Icelandic media. At the same time, however, it appears that, on the relatively few occasions that female athletes get media attention in the first place, the coverage is slightly more thorough than is the case for male athletes. Also, pictures taken specifically for the article in question more often accompany coverage of women's sports than men's sports.

A more detailed analysis of the discourse itself and its gender aspects, as these appear in Icelandic newspapers, can be seen in a recent study by Sæmundsson (2012, 2014). In this study, which was a part of his Ph.D. thesis, Sæmundsson examined the discourse in relation to 19 successful Icelandic athletes, five of whom were women, in a total of 984 newspaper articles, most of which were from the late 1990s and the first few years of the twenty-first century. He concludes that this discourse can only be said to be gendered when it circles around the female athletes as it is only in their case that the athletes' gender is a separate issue. Thus, the female athletes included in the study tend to be regarded as women no less than as athletes, through frequent references about e.g. their beautiful smiles or their strong emotions, or about them as fair maidens, at the same time as photographs accompanying the articles tend to emphasize their female figure. Similarly, the female athletes' high levels of ambition are often mentioned, but this characteristic seems to be taken for granted when it comes to male athletes and their masculinity rarely enters the discussion in any direct way as, according to Sæmundsson, it is not necessary to point it out specifically in the highly masculine world of sports. 
Despite this general picture of imbalance there are some signs that sports writers and reporters are starting to view female athletes in much the same way as male athletes, at least in certain sports. In her B.Ed. thesis, Karítas Pórarinsdóttir (2012) examined the coverage of, on the one hand, Iceland's national men's football team and, on the other, the women's national team and found few clear differences in the discourse regarding the two teams. There seemed to be a tendency to criticize the men's team somewhat more harshly than the women's team after a loss, and individual male players were singled out in this respect while the women's team as a whole was criticized, but otherwise the discourse followed the same lines for both teams. A possible reason for this is that the women's national team has in recent years been quite successful; it has reached the finals of the European Championship on three occasions, most recently for the upcoming 2017 finals in the Netherlands, and is ranked as one of the stronger teams in Europe. Meanwhile the men's team has lagged behind in this regard, and thus the women's team may have earned some extra respect, compared to the men's team, amongst sports journalists. It is also noteworthy that the phrase "spila eins og kerlingar" ("play like chicks"), which was, until recently, almost a standard phrase to describe a bad performance by a men's team, is now frequently used, albeit somewhat lightheartedly, as a positive description amongst the general public, probably mainly thanks to the recent successes of the women's national team. It should be noted, however, that in 2016 the men's team qualified for the first time for the finals of a major tournament, the European Championship in France, and even reached the quarter-finals. No formal analysis has been carried out of the effects of this as regards media coverage of men's vs. women's football in Iceland, but it seems safe to say that the success of the men's team by and large overshadowed the women's team's latest achievements both during the tournament in France and in the following months.

Furthermore, the positive example above, of the more or less equal standing of female and male athletes in Icelandic sports coverage, is an exception, and on the whole there appears to be a clear imbalance, in terms of both quality and quantity, in how sports journalist view athletes depending on their gender. This has not gone unnoticed by the general public, at least not the more feministically minded part of it. Thus, this topic has been taken up in a few blog posts on the previously mentioned Knúz website and it also pops up at regular intervals in various social media. The most noticeable contribution in this regard is probably that of Guðrún Harpa Bjarnadóttir, who followed the daily sports coverage in Fréttablaðið, one of the largest newspapers in Iceland, throughout the year 2015 (with the exception of August, when she was away on holiday). She posted her results through status updates on her personal Facebook page and also first declared her intentions and later wrote a summary of these results in two separate articles on the Knúz webpage (2015, 2016). Bjarnadóttir's approach is primarily quantitative and in her summary of 2015 (2016) she points out that, all in all, men's sports got $72.5 \%$ of the coverage while women's sports got $22.4 \%$ of it. The remaining $5.1 \%$ consists of coverage where the genders are mixed in one way or another. She also breaks these figures down a little further and mentions e.g. that on a week-to-week basis, men's sports get the majority of the coverage in 46 of the 48 weeks that she followed, while women's sports have the upper hand in only two weeks. Similarly, on a total of 52 days the coverage included only one of the genders and on 51 of these days men's sports were the only topic of discussion. 
Bjarnadóttir also makes a few qualitative observations and she points out that, on the few occasions that female athletes are the main topic of news articles, the emphasis seems more often than not to be placed on their womanhood rather than on their athletic achievements, such as in the case of a top female handball player who scored 16 goals in a single game, which the reporter in question seemed to find all the more remarkable as she is the mother of three children (Bjarnadóttir 2015). This, of course, quite neatly mirrors the findings of Sæmundsson $(2012,2014)$ discussed above.

Even though sports coverage appears to have been the main field of study when it comes to gendered discourse, at the same time as it has been the main topic in the public debate on the matter, other themes have been touched upon. One of these is politics, but according to a recent B.A. thesis (Ingvarsdóttir 2012) female politicians face much the same situation as female athletes in that they tend to be discussed no less than women than as politicians in the media. This is evident in frequent references to female politicians' appearance and clothing, and to various aspects of their personal lives, their families in particular, which male politicians are by and large freed of, at the same time as reporters tend to primarily interview female politicians on topics that are perceived as "soft", e.g. the welfare system.

Another theme that has been examined to some extent in relation to gendered discourse is children's literature and the frequent stereotyping of gender roles in it. According to Pórarinsdóttir (2013), who is herself a writer of children's literature, girls in children's books are generally portrayed as responsible, passive and placid, and their main aim in life is more often than not to become a princess or a caring mother, while boys are presented as adventurous and carefree and they have a wide range of exciting career choices, such as pirate or astronaut. This distinction is further accentuated by the decoration in the books, where the girls' world is predominantly in pink tones while that of the boys is blue.

In an examination of then newly published school books to be used in the teaching of history at primary level in Icelandic schools, Guðmundsson (2010) points out that women are to a large extent neglected in this material and that little progress seems to have been made since an earlier examination by Porvaldsdóttir (1996) which showed that women accounted for between $2.1 \%$ and $21.2 \%$ of the persons named in the 24 school books in history taken into consideration. Both Guðmundsson (2010) and Porvaldsdóttir (1996) also mention that it is strange that so far not a single woman has authored a school book on Icelandic history. Porvaldsdóttir (2002) has also made an interesting study of possible differences in the evaluation of male and female candidates applying for academic positions at the University of Iceland. Here she found that while a strongly gendered discourse was an exception rather than the rule in the 35 evaluations she studied, there were examples of stereotypical masculine values of strength and industry, and female virtues and conscientiousness being foregrounded when the candidates' credentials were accounted for.

Some studies also exist on the gendered discourse that can be said to reside in the Icelandic language itself, through the vocabulary that exists and is used to refer to men on the one hand and women on the other. The links to the language reform issues mentioned above are obvious, but the studies that are relevant here serve only to describe the current state without any particular reform agenda. A study by Kvaran (1996) can function as an example of these studies. She searched the main dictionary of the Icelandic language, the main etymological dictionary, and a database of spoken Icelandic hosted at the University of 
Iceland for terms used for men and women and categorized them depending on whether their connotations were neutral, positive or negative, and on the personal characteristics that they referred to. Kvaran found that for both men and women the majority of the terms she found were negative while there were relatively few neutral or positive terms for both genders. However, there were some differences regarding which personal characteristics were the source of the terms. Thus, there appears to be plenty of terms in Icelandic that refer to rough and rude men while terms of that nature that refer to women are much fewer. Similarly, there are more terms to describe men that are regarded as silly or daft. Conversely, there is a greater number of terms that refer to the physical appearance of women than that of men, and terms that refer to promiscuity much more commonly describe women than men.

Another theme that links directly to the previously discussed language reform issues is that of the queer discourse in Iceland. In her master's thesis, Steinarsdóttir (2010) can be said to follow up on Hjartardóttir's (2004) work mentioned above on how Samtökin '78 and the gay community in Iceland in general fought for the recognition and general use of terms such as hommi and lesbia that this group used to refer to its own members. For her thesis, Steinarsdóttir (2010) carried out a discourse analysis of the use of these terms on the pages of Morgunblaðið, a leading Icelandic newspaper, from 1920-2006. Her main conclusion is that the queer discourse has in modern times become firmly established on its own terms, e.g. such that hommi and lesbía have become commonplace terms and that samkynhneigð ("homosexuality", lit. "same-gender orientation") has almost fully replaced the older term kynvilla ("sexual orientation error"). Interestingly, however, Steinarsdóttir, like Hjartardóttir (2004) a few years before her, found that hommi is more frequently used than lesbia, for much the same reasons.

\section{Gender and language use}

The third and final category into which work on language and gender in Iceland falls into is that of gender and language use, i.e. whether or not there are signs in Icelandic of linguistic variation according to the gender of the speaker, and how this variation appears. In contrast to the subject matter of the other two categories discussed in this article, this topic does not appear to have occupied the general public too much, at least not to the extent that it has been taken up for any direct discussion in blogs, on social media or other such venues. Nevertheless, the general public is very much involved in this topic, albeit in a somewhat indirect way, as it is of course mainly the gender aspects of its use of language that researchers in the field are interested in.

As is the case in the other two categories discussed above, this category includes only a handful of scientific studies, and most of these are fairly small in terms of their scope and content. The first of these studies, which is also probably the first Icelandic study to address the issue of language and gender in any direct way, was carried out by Stefánsdóttir in 1987. In the study some gender differences were found amongst Icelanders in the use of colour terms and adjectives. However, Stefánsdóttir can mainly be credited with taking the first steps in this direction as the study's results are of very limited value for methodological reasons. 
Other studies in this category include e.g. that of Hjartardóttir (1997), who found that men in the Western Fjords of Iceland showed greater allegiance to the local dialect than women did, both in terms of their attitudes towards the dialect and in their actual use of it. More recently, Porgrímsdóttir (2010) examined, in her B.A. thesis, whether gender differences could be found in the use of Icelandic Sign Language. Her conclusion, which, as she takes care to point out, is based on a very low number of users, is that the small differences she found are individual rather than relatable to gender in any direct way. She goes on to speculate as to whether this can be related to the fact that all sign language interpreters in Iceland are women, as are all teachers in Icelandic preschools where sign language is used, and all primary school teachers but one who know sign language, which means that the linguistic role models of deaf children in Iceland are predominantly women.

Yet another student thesis can be mentioned here as a final example of work that directly addresses gender and language use in Iceland. It has strong links to some of the work discussed above in relation to feminist language reform in that it examines the issue of linguistic gender in Icelandic, albeit in a slightly different way. In this M.A. thesis Ragnarsdóttir (2014), drawing on the work of e.g. Lakoff (1975) and Pauwels (1998), analysed broadcast interviews with male coaches of women's teams in basketball, football and handball in order to see whether they showed any tendency to feminization and the use of semantic or biological agreement rather than standard grammatical agreement. The coaches were also asked to fill out a written questionnaire for the same purpose. The results show that the coaches used feminized forms on $75 \%$ of the possible occasions in the written questionnaires and on $57 \%$ of the relevant occasions in free speech in interviews. This means that more often than not the coaches used phrases such as "við (n.pl) vorum yfirspilaðar (f.pl)" ("we were outplayed"), thus including themselves in the group of female players rather than separating themselves from it by using "við (n.pl) vorum yfirspiluð (n.pl)". Similarly, the coaches were found to use a phrase like "leikmennirnir (m.pl) eru allar (f.pl) góðar (f.pl) í handbolta" ("the players are all good at handball") where, through the masculine plural noun leikmennirnir, standard grammatical agreement requires "leikmennirnir (m.pl) eru allir (m.pl) góðir (m.pl) í handbolta". In this way, the coaches underline that the group of players consists of women and Ragnarsdóttir argues that this is, at least on occasion, a conscious choice.

Apart from the studies mentioned above, gender has on a few occasions been an indirect issue on studies regarding the use of Icelandic, mainly in that it has been one of the social background variables that is correlated with various kinds of linguistic variation. Thus, studies on Icelandic dialects generally include a gender aspect and some of them, just like Hjartardóttir's (1997) study discussed above, indicate that the familiar pattern of women adhering more closely to standard language while men hold on to local dialects also applies to Iceland (Gunnlaugsson 1984; Práinsson \& Árnason 1986; see also e.g. Norrby \& Håkansson 2010; Wodak \& Benke 1998 for overviews of this general pattern). Similarly, most Icelandic studies on language change take gender into account to some extent and while they generally show only small gender-related differences the few signs that do appear point in a direction similar to that in the dialectal studies as men appear to be slightly more likely than women to accept and use new, non-standard, forms while women stay closer to standard language (Friðriksson 2008; Jónsson \& Eypórsson 2003; Sigurjónsdóttir \& Maling 2001; Svavarsdóttir, Pálsson \& Pórlindsson 1984). Finally, there are some suggestions that in terms 
of attitudes towards language change in Icelandic, women are more conservative than men (Friðriksson 2008).

\section{Gender and language use in social media}

To round off this discussion on gender and language use, a brief presentation will now be given of some ongoing work by the author of this article. This work addresses the issue of language and gender in social media, Facebook in particular, and is presented here mainly to give an indication of the possible direction that work on language and gender in general in Iceland might take in the nearest future.

It is probably needless to point out that social media and online communication in general has had a growing influence on language use in most corners of the world over the last few years and, as could be expected, this has sparked plenty of research on these issues as well. However, Facebook appears to have received relatively limited attention in the linguistics camp - although issues such as bilingual language use in this medium (Androutspoulos 2015; Cunliffe, Morris \& Prys 2013; Riley 2013; Sharma 2012), as well as the use of different speech acts for different purposes (Carr, Shrock \& Dauterman 2012; Ilyas \& Khushi 2012) have been addressed - and the possible interaction between language and gender in this medium even less. Thus, with a few exceptions, such as Garcia-Gomez's (2011) study of how teenage girls use linguistic strategies to attack and humiliate one another on Facebook, the role of gender in Facebook language use has largely been ignored by linguists. However, a few glimpses can be found elsewhere, especially in more psychologically oriented work. Thus Joiner, Cuprinskaite, Dapkeviciute, Johnson, Gavin \& Brosnan (2016) found that women show higher levels than men of emotional support when responding to so-called status updates from Facebook friends of the same gender, and, in a study of 10 million Facebook messages from more than 52,000 users, Park et al. (2016) found that while women use warmer and more affiliative language than men, no clear gender differences could be seen as regards assertive language. The results presented below can, at least in part, be viewed in light of these findings. At the same time, the present results should not be regarded as anything more than a tentative step towards a closer examination, in an Icelandic context, of the potential role of gender in e.g. the linguistic presentation of self on Facebook and the use of various linguistic means to get different messages across in this medium of communication. This is due both to the limitations of the work the results are based and the fact that no prior work of this kind exists in Iceland.

The first stage of the work consisted of a pilot study, the main aim of which was to identify which aspects called for further examination. In the study, the news or home page of two Facebook users was observed for 48 hours. On this page, both the user's status updates and those of their Facebook friends appear, together with comments made to these updates by both the user and his or her friends, as well as other friends of these friends whom the owner of the Facebook page studied may not be immediately linked to. These status updates and the comments made on them were the data gathered and analysed for this pilot study, but in the 48 hours in question a total of 199 status updates appeared on the two Facebook pages. These updates were made by 113 different individuals: 60 women, who made a total of 106 updates, and 43 men, who made the remaining 96 updates. To these status updates a total of 516 
comments were made, by 362 different individuals; 201 of these were women, and they are responsible for 261 of the comments, while the 161 men made 255 comments. As for the two people whose Facebook pages were observed, they were, on the one hand, a woman in her late thirties and, on the other, a man in his early forties. They both describe themselves as active Facebook users, in the sense that they regularly post status updates on their own page and comment on the updates of others. It should be noted, though, that in the 48 hours that their pages were observed, the man only posted one status update and commented on two such updates from his friends, while the woman did not post any status updates and commented on three updates from friends. Thus, they can primarily be described as the "hosts" of this pilot study, as their contribution in terms of linguistic data is on a level similar to that of those of their friends whose actions appeared on their pages during the period of observation.

In these status updates, the users can take up most any topic they like, and the first step was to analyse what subjects were written about. Hence the updates were divided into categories such as "everyday issues" (which includes updates regarding e.g. family dinners or holidays, recounts of the user's own doings during the day, etc.), "politics", "society/news" and "sports". Of these, "everyday issues" was the most common one, comprising 64 of the total 199 status updates, i.e. nearly one third. More interestingly, however, for the purposes of this article there was a clear gender division in some categories while it was less evident in others. Thus, men dominated the "sports" category, with eight contributions against only one from women, and the "music/movies" category, where 12 of the total 14 contributions came from men, while women were responsible for all four contributions in the "clothes/fashion" category and six of the seven contributions in the "food" category. Women also produced nearly twice as many status updates as men in the "everyday issues" category, i.e. 41 against 23. It should be noted, however, that this means that $39 \%$ of the women's updates were of this kind while the corresponding figure for men is $24 \%$, which suggests that the difference may not be as large as the sheer numbers indicate, at the same time as the number of contributions from men suggests that this is not a topic that they generally shy away from. Finally, the contributions in the "society/news" and "politics" categories were relatively evenly divided between the genders, with women producing 30 of the 53 contributions in the former category and 12 of the 27 in the latter.

As mentioned above, all 516 comments made to the 199 status updates were also analysed. From a gendered point of view, it is probably most interesting to note that here, as in the case of the status updates, some of the stereotypical gender patterns appear, with a few noteworthy exceptions. Thus, the results indicate that, in their comments, Facebook users primarily react to status updates made by users of their own gender. Furthermore, the genders are almost a perfect mirror image of each other in that $76 \%$ of all women's comments found in this study were made to status updates from other women while $75 \%$ of all men's comments were made to status updates from other men. A closer look also reveals that on the relatively few occasions that women react to men's status updates they most often do so when these updates circle around everyday issues while men hardly react at all to women's updates on such issues. Rather, men tend to comment on women's updates when these stray into typically "male" topics, such as the "sports" category mentioned above. Finally, if men react to other men's updates on everyday issues, this is often done in the form of teasing or light insults. 
As indicated earlier, there are some exceptions to this general pattern in the comments. Thus, there are examples of men commenting in a very sincere way on other men's updates on everyday issues, e.g. in the case of a man who responds with "falleg börn" ("beautiful children") to pictures of another man's grandchildren that he posted with one of his status updates, and in that of a man who reacts with "samúðarkveðjur, kæri vinur" ("my condolences, my dear friend") to some sad news related in an update by his friend. Similarly, not all the contributions made by women fall in line with the stereotypical "feminine" style, as is made clear by the following status update (in my translation):

Now I can't keep it in any longer so I'll let it out, countryside style: Goddamit how much I'd like to get rid of this fucking snow from the pavements and be able to run (and then I mean run, not skate or crawl) along the streets in this wonderful weather that we have now. I'm getting bloody tired of this damned ice which has been here these last few months.

This update is then immediately followed by a comment which runs very much along the same lines and is made by a woman.

Finally, it quickly became quite clear during the analysis of the data that the men and women who wrote on the two Facebook pages during the 48 hours in question used both emojis (i.e. signs of this kind: ()) and exclamation marks both to a different degree and for different purposes. Thus, the women used smileys on 27 occasions and while they were of eight different types they were always used in a positive or humorous context. The men, on the other hand used smileys on only 8 occasions and two of the three different types used were frowning smileys, used to underline an angry or negative comment. Similarly, women used (one or more) exclamation marks more frequently than men; on 45 vs. 26 occasions, and there was also a clear difference regarding the context in which they were used. The women generally used them in connection with everyday or social issues while the men used them in relation to updates or comments regarding sports, cars or politics.

In the pilot study just described, teenagers were by and large absent as they appear not to write Facebook status updates or comments on them to the same extent as adults do. To get some insight into teenagers' activities on Facebook, linguistic or otherwise, the pilot study was followed up by a study where this group takes centre stage. For this study, which is still ongoing, a group of 92 teenagers, 48 girls and 44 boys, gave the researchers access to their Facebook pages for a period of three weeks. These teenagers were recruited with visits to two different high schools: one which primarily focuses on vocational training and one which is more academically oriented. Twenty-five girls and 22 boys were recruited from the former and 23 girls and 22 boys from the latter. Care was also taken to recruit students from different lines of study within each of the schools.

During the three weeks of examination, the teenagers' activities were tracked and analysed, as well as all the material on their Facebook pages that is not locked or hidden from public view in one way or another. Furthermore, 30 of the participants provided examples of their writing in the messenger function of Facebook, which is a system that functions much like MSN messages did in their time. Finally, two focus group interviews were conducted, to follow up some of the initial findings.

From a language and gender point of view the first results from this study are primarily interesting due to the fact that gender appears in most ways to be a secondary issue and the 
teenagers are, regardless of their gender, more occupied with exploring and adapting to the possibilities and restrictions that come with the Facebook medium. Thus, while teenage girls seem to be somewhat more active than teenage boys in terms of writing status updates, as they wrote an average of 6.23 updates over the three-week period as compared to 3.98 amongst the boys, very few qualitative differences are discernible. Thus, both genders generally use standard written language and adhere closely to standard punctuation in their updates, which, as was confirmed in the focus groups interviews, is relatable to the fact that the teenagers are aware that their updates are open for all their Facebook friends, including, in most cases, their parents and even grandparents whom the teenagers do not want to upset with bad or foul language.

Messages sent via Facebook are, on the other hand, only visible to those they are sent to and this means, by the teenagers' own admission in the focus group interviews, that "anything goes" in terms of language, at least when they are writing to their peers. This in turn means that the language tends to be highly informal and shows few signs of editing in terms of spelling, punctuation, various inflections or even sentence structure. Slang is frequently used, as are abbreviations of a very varied nature, and the text can be said to be on many levels in the sense that it generally contains frequent links to material on other media such as Youtube, various news/sports/entertainment websites, and other social media. However, these characteristics apply in equal measure to texts from both genders, with the possible exception that boys show a slightly greater propensity to use highly explicit language, i.e. strong swear words and sexual references. Interestingly, the teenagers' expression appears to be more gendered when its visual aspect is examined as photos posted by the girls often display them together with their families and/or boyfriends, while there appears to be little room for either family or girlfriends in photos posted by the boys; this space is rather taken by their friends or sports stars or other celebrities, almost all of whom are male.

\section{Conclusion}

This article has strayed far and wide in attempt to give an overview of how the topic of language and gender has been treated in Iceland, in academic circles as well as among the general public. As can be seen, a number of issues have been touched upon within this framework and they can roughly be categorized into the three themes that form the structure of this article, i.e. feminist and/or queer language reform, gendered discourse and gender and language use. The little scientific work that exists on these issues indicates that in general the language and gender patterns in Iceland do not differ in any significant way from those found in comparable societies. This means e.g. that while there may be some aspects of the Icelandic language and the use of it that are more characteristic of one of the genders, care should be taken not to look at the more female and the more male aspects as binary oppositions or mutually exclusive categories as there are plenty of examples from either side that this should rather be regarded as a scale or a spectrum along which each individual can, regardless of gender, glide from one end to the other according to needs and circumstances at any given time.

At this point, however, the points just mentioned can not be seen as anything more than slight indications, and if any general conclusion can be now made about language and gender 
in an Icelandic context it is that much more work is needed before any real conclusions can be drawn. Apart from the three categories mentioned above, very few clear trends have yet appeared and much more depth, through systematic studies, is needed for the picture to become clearer. Hopefully, this overview and the indications given in it about possible future directions can function as an inspiration for further work, which can in turn raise awareness about language and gender issues in Iceland, amongst scientists and the general public alike.

\section{References}

Androutspoulos, Jannis. 2015. Networked multilingualism: Some language practices on Facebook and their implications. International Journal of Bilingualism 19(2):185-205.

Bjarnadóttir, Guðrún Harpa. 2015. Kynlegar ípróttafréttir. Knúz - feminískt vefrit. https://knuz.wordpress.com/2015/02/02/kynlegar-ithrottafrettir/

Bjarnadóttir, Guðrún Harpa. 2016. Kynlegur ípróttaannáll 2015. Knúz - feminískt vefrit. https://knuz.wordpress.com/2016/01/06/kynlegur-ithrottaannall-2015/

Carr, Caleb T., Shrock, David B. \& Dauterman, Patricia. 2012. Speech Acts Within Facebook Status Messages. Journal of Language and Social Psychology 31(2):176-196.

Cunliffe, Daniel, Morris, Delyth \& Prys, Cynog. 2013. Young Bilinguals' Language Behaviour in Social Networking Sites: The Use of Welsh on Facebook. Journal of Computer-Mediated Communication 18:339-361.

Daðason, Kolbeinn Tumi. 2012. Ípróttafréttamennska á Íslandi: Ípróttaumfjöllun um karla og konur á íslenskum vefmiðlum. Unpublished M.A. thesis, University of Iceland.

Eckert, Penelope \& McConnell-Ginet, Sally. 2003. Language and Gender. Cambridge: Cambridge University Press.

Edlund, Ann-Catrine, Erson, Eva \& Milles, Karin. 2007. Språk \& kön. Stockholm: Norstedts Akademiska Förlag.

Friðriksson, Finnur. 2008. Language change vs. Stability in conservative language communities: A case study of Icelandic. Doctoral thesis. Gothenburg: University of Gothenburg.

Garcia-Gómez, Antonio. 2011. Regulating girlhood: Evaluative language, discourses of gender socialization and relational aggression. European Journal of Women's Studies 18(3):243-264.

Guðmundsson, Bragi. 2010. Nýjar Íslandssögur fyrir miðstig grunnskóla. Ráðstefnurit Netlu - Menntakvika 2010. http://netla.hi.is/menntakvika2010/alm/004.pdf

Gunnarsdotter Grönberg, Anna. 2002. Masculine generics in current Icelandic. In Marlis Hellinger \& Hadumod Bußmann (eds.) Gender across languages. The linguistic representation of men and women. Volume 2. Amsterdam/Philadelphia: John Benjamins, pp. 163-185.

Gunnlaugsson, Guðvarður Már. 1984. Tölfræðileg málvísindi (eða málfræðileg tölvísindi). Íslenskt mál og almenn málvísindi 6:177-181

Helgadóttir, Anna. 2011. Notkun málfrceðilegra kynja i máli ungs fólks: Rannsókn á kynjanotkun í íslensku máli. Unpublished M.A. thesis, University of Iceland.

Hjartardóttir, Póra Björk. 1997. Framburður, viðhorf og kynferði. In Helga Kress \& Rannveig Traustadóttir (eds.) Íslenskar kvennarannsóknir. Reykjavík: Háskóli Íslands, Rannsóknastofa í kvennafræðum, pp. 67-76.

Hjartardóttir, Póra Björk. 2004. Baráttan um orðin. Orðanotkun tengd samkynhneigð. Íslenskt mál 26:83-122.

Ilyas, Sanaa \& Khushi, Qamar. 2012. Facebook Status Updates: A Speech Act Analysis. Academic Research International 3(2). 
Institutet för språk och folkminnen. 2015. Frågelådan: Har en börjat användas i stället för man i skrift? http://www.sprakochfolkminnen.se/sprak/sprakradgivning/frageladan. html?url=-27634753\%2Fcgi-bin\%2Fsrfl\%2Fvisasvar.py\%3Fsok\%3Den\%26svar\%3D7 8373\&sv.url=12.c17e514db30bb2a810ea

Ingvarsdóttir, María Lind. 2012. Куnјuð orðraða i fjölmiðlum: Orðræððugreining fjölmiðlaumfjöllunar um frambjóðendur Sjálfstaðisflokksins $i$ aðdraganda formannskosninga flokksins í nóvember 2011. Unpublished B.A. thesis, University of Iceland.

Íslenska til alls: Tillögur íslenskrar málnefndar að íslenskri málstefnu sampykktar á Alpingi 12. Mars 2009. 2009. Reykjavík: Mennta- og menningarmálaráðuneyti.

Joiner, Richard, Cuprinskaite, Juste, Dapkeviciute, Lina, Johnson, Helen, Gavin, Jeff \& Brosnan, Mark. 2016. Gender differences in response to Facebook status update from same and opposite gender friends. Computers in Human Behavior 58:407-412.

Jónsson, Jóhannes Gísli \& Eypórsson, Pórhallur. 2003. Breytingar á frumlagsfalli í íslensku. Íslenskt mál og almenn málfrææi 25:7-40.

Kendall, Shari \& Tannen, Deborah (2003). Discourse and Gender. In Deborah Schiffrin, Deborah Tannen \& Heidi E. Hamilton (eds.) The Handbook of Discourse Analysis. Malden: Blackwell, pp. 548-567.

Knútsdóttir, Hildur. 2013a. Pegar tungumálið talar okkur. Knúz - feminískt vefrit. https://knuz.wordpress.com/2013/04/09/thegar-tungumalid-talar-okkur/

Knútsdóttir, Hildur. 2013b. Svar við svari Irisar. Knúz - femínískt vefrit. https://knuz.wordpress.com/2013/04/23/svar-vid-svari-irisar/

Kulick, Don \& Cameron, Deborah. 2003. Language and Sexuality. Cambridge: Cambridge University Press.

Kvaran, Guðrún. 1996. Ambindrylla og puðrureddi: Um heiti karla og kvenna. Íslenskt mál og almenn málfræeði 16-17:171-208.

Lakoff, Robin. 1975. Language and woman's place. New York: Harper \& Row.

Milani, Tommaso M. 2014. Queering Masculinities. In Janet Holmes, Miriam Meyerhoff \& Susan Ehrlich (eds.) The Handbook of Language, Gender and Sexuality (2nd ed.). Hoboken: Wiley Blackwell, pp. 260-278.

Norrby, Catrin \& Håkansson, Gisela. 2010. Introduktion till sociolingvistik. Stockholm: Norstedts

Nowenstein, Iris Edda. 2013. Að gera málkerfið að karlrembusvíni. Knúz-femínískt vefrit. https://knuz.wordpress.com/2013/04/17/ad-gera-malkerfid-ad-karlrembusvini/

Ólafsson, Kjartan (ed.). 2006. Sports, media and stereotypes - women and men in sports and media. Akureyri: Jafnréttisstofa.

Park, Gregory, Yaden, David Bryce, Schwartz, H. Andrew, Kern, Margaret L., Eichstaedt, Johannes C., Kosinksi, Michael, Stillwell, David, Ungar, Lyle H. \& Seligman, Martin E. P. 2016. Women are Warmer but No Less Assertive than Men: Gender and Language on Facebook. PLOS One 11(5)

doi: 10.1371/journal.pone.0155885

Pauwels, Anne. 1998. Women Changing Language. London: Longman.

Queen, Robin. 2014. Language and Sexual Identities. In Janet Holmes, Miriam Meyerhoff \& Susan Ehrlich (eds.) The Handbook of Language, Gender and Sexuality (2nd ed.). Hoboken: Wiley Blackwell, pp. 203-219.

Ragnarsdóttir, Guðbjörg Elín. 2014. Leikmennirnir eru allar góðar í handbolta: Rannsókn á kynjanotkun í máli karlpjálfara ípróttaliða kvenna. M.A. thesis, University of Iceland.

Riley, Jacqueline. 2013. Bilinguals' Use of English and Spanish Digitalk on Facebook Status Updates. International Journal of English Linguistics 3(1):1-18. 
Samtökin '78. 2015a. Hýryrði 2015: Nýyrðasamkeppni Samtakanna '78. http://www.sam tokin78.is/frettir/nyjar-frettir/5851-hyryrdhi-2015-nyyrdhasamkeppni-samtakanna-78

Samtökin '78. 2015b. Burið mitt er vífguma - hýryrði 2015. http://www.samtokin78.is/frettir /nyjar-frettir/5908-buridh-mitt-er-vifguma-hyryrdhi-2015

Sharma, Bal Krishna. 2012. Beyond social networking: Performing global Englishes in Facebook by college youth in Nepal. Journal of Sociolinguistics 16(4):483-509.

Sigurjónsdóttir, Sigríður \& Maling, Joan. 2001. Pað var hrint mér á leiðinni í skólann: Polmynd eða ekki polmynd? Íslenskt mál og almenn málfraeði 23:123-180.

Stefánsdóttir, Steinunn. 1987. Um mun á orðavali kvenna og karla. Mímir 35:17-27.

Steinarsdóttir, Gunnhildur. 2010. Frá kynvillu til kynhneigðar: Hvað einkennir orðraæðuna nú pegar baráttan um orðin er unnin. Unpublished M.A. thesis, University of Iceland.

Svavarsdóttir, Ásta, Pálsson, Gísli \& Pórlindsson, Pórólfur. 1984. Fall er faraheill: Um fallnotkun með ópersónulegum sögnum. Íslenskt mál og almenn málfrææði 6:33-55.

Sæmundsson, Guðmundur. 2012. Svo sæt og brosmild... Umfjöllun í blöðum og tímaritum um íslenskar afreksípróttakonur á alpjóðavettvangi. Netla - Veftímarit um uppeldi og menntun. http://netla.hi.is/greinar/2012/ryn/008.pdf

Sæmundsson, Guðmundur. 2014. Dað er noesta víst ... : Hvað einkennir einkum umfjöllun um ípróttir í íslenskum fjölmiðlum og bókmenntum. Doctoral thesis. Reykjavík: University of Iceland.

Vilhjálmsdóttir, Auður Eir. 2005. Mál beggja kynja. Skíma 28(2):42-43.

Villiljós, Alda. 2013. Hán - nýtt persónufornafn? Knúz - femínískt vefrit. https://knuz.wordpress.com/2013/09/09/han-nytt-personufornafn/

Wodak, Ruth \& Benke, Gertraud. 1998. Gender as a Sociolinguistic Variable: New Perspectives on Variation Studies. In Florian Coulmas (ed.) The Handbook of Sociolinguistics. Malden: Blackwell, pp. 127-150.

Porgrímsdóttir, Rúna Vala. 2010. Um kynjamun í málfari: Rannsókn á kynbundnum málfarsmun í íslensku talmáli. Unpublished B.A. thesis, University of Iceland.

Porvaldsdóttir, Porgerður. 1996. Нvað er svona merkilegt við pað að vera karlmaður? Athugun á hlut kvenna í kennslubókum í sögu fyrir grunn- og framhaldsskólanema. Saga, tímarit Sögufélags 34:273-305.

Porvaldsdóttir, Porgerður. 2002. “Kynlegar víddir í dómnefndarálitum?” Er kynbundinn munur á umfjöllun um karl- og kvenumsækjendur í dómnefndarálitum Háskóla Íslands? Reykjavík: Jafnréttisnefnd Háskóla Íslands.

Pórarinsdóttir, Brynhildur. 2013. Prúðar prinsessur og svellkaldir sjóraningjar. Paper presented at Jafnréttistorg Kennaradeildar Háskólans á Akureyri. University of Akureyri, January 23rd.

Pórarinsdóttir, Karítas. 2012. Orðræða fjölmiðla og íslenskra A-landsliðsmanna um kvennaog karlaknattspyrnu. Unpublished B.Ed. thesis, University of Iceland.

Pórhallsdóttir, Guðrún. 2005. Hvað mælir gegn “máli beggja kynja”? Skíma 28(2):44-47.

Pórhallsdóttir, Guðrún. 2008. Karlkyn eða hvorugkyn? Íslensk málhefð, feminísk málstýring og verkefni pýðingarnefndar. Glíman 5, pp. 103-133.

Práinsson, Höskuldur \& Árnason, Kristján. 1986. Um skagfirsku. Íslenskt mál og almenn málfrceði 8:31-62. 